\title{
correspondence
}

\section{Mosquito research}

SIR,-The article by Narender $K$. Sehgal (Nature, September 20) entitled "Doubts over US in India" is misleading and misinformed. The article repeats some of the allegations which have been made during the past few months in the Indian press about current mosquito research in Delhi, but it omits many subsequent retractions in the same press.

The Research Unit for Genetic Control of Mosquitos in Delhi is a joint venture of the Indian Council of Medical Research and the World Health Organisation. The unit was established about five years ago to study the ecology of three of the major disease vectors of India, Culex pipiens fatigans, Aedes aegypti and Anopheles stephensi, and to investigate genetic mechanisms which might be utilised for their control. All three are difficult to control by conventional methods, not only in India but throughout their distribution range. The research programmes were planned in India by ICMR and WHO scientists who, collectively, represented a range of disciplines and who shared a wide experience of vector-borne diseases. It is clear from the erroneous and misleading statments on filariasis, dengue and malaria that neither $\mathrm{Mr}$ Sehgal nor his informants are qualified to judge the scientific aspects of the programme, which makes it all the more reprehensible that they themselves have not taken the "closer look at the related details" of the "seemingly scientific investigations" which they recommend to others. The details are readily available. A whole issue of the Journal of Communicable Diseases published in the middle of 1974 in Delhi describes the programme. There is no secrecy, as has been charged, about the work. Having been closely associated with the unit and its staff for five years, both as a consultant and Project Leader, I can give this assurance unreservedly.

The main charge in the controversy, unfortunately still current, is that the data being collected on mosquito ecology may be, or are being, misapplied in some fashion relating to biological warfare. The same charge could equally well be laid in India and elsewhere against work being done on insect vectors of plague, viral encephalitis and typhus. The results from a great deal of biological and medical research could in theory be misapplied, but this is a poor argument for criticis. ing studies specifically designed for the long-term benefit of the community. If the interpretation of current mosquito research presented by $\mathrm{Mr}$ Sehgal is genuinely believed by some nonmedical Indian authorities, then there is clearly a sad lack of understanding of the integrity and objectives both of local and foreign scientists in India and of international agencies.

There is nothing unusual about the financial support of the mosquito unit from US PL480 Indian funds. Scores of other research projects in India carried out by Indian scientists have been supported from the same source. The political implications that have been made have damaged relationships within the medical science community, and their continuance can only hinder progress in controlling mosquito-borne disease.

Sir Ronald Ross often expressed his frustration and discouragement when his research in India on Culex pipiens fatigans and bird malaria, which subsequently won him a Nobel prize, was misconstrued and retarded by the authorities of his day. It will be disheartening if, 75 years later, his successors suffer the same discouragement.

\section{W. W. Macdonald} Liverpool School of Tropical Medicine, Liverpool, UK

\section{Protests}

Sir,- My letter published in your issue of August 12 set out the unequivocal policy of the World Federation of Scientific Workers on the rights of scientists to work and the procedure for imolementing this policy in specific cases. Professor Janouch (Nature, September 20) does not approve of our policy and believes that "only open, public stands, protests and statements are meaningful and helpful". My own experience in working in international organisations over many years has taught me that, from the point of view of he!ping individuals in difficulty, not less than preserving the integrity of the organisation, an informal, low-key approach may often be more effective than the attitude he advocates.

Surely, also, before making protests and statements one should seek to discover whether the facts of the case have been fully and accurately presented. This is what our procedure tries to do and often, as in fact has hap- pened in the particular case that led to this correspondence, new facts show the matter in a somewhat different perspective.

The case of Professor Holzer, referred to in Dr Janouch's letter, is much more serious than he claims because it is based on a law existing already in certain West German Länder and currently being prepared for submission to the Federal Parliament, whereby a whole category of people, members of certain legal parties and organisations, such as the German Communist Party (DKP), can be debarred from employment in public service posts, including posts as school teachers, judges and university teachers.

Dr Janouch also mentions the case of Academician Ivan Malek, who gave dedicated and distinguished service to the Federation over many years. Those who have heard or read addresses I have made to meetings of the Federation in recent years will be in no doubt about the high esteem and affection in which he is held in the Federation. Academician Malek was an active supporter of Alexander Dubcek and lost his posts as Director of the Institute of Microbiology in Prague and as a VicePresident of the Czechoslovak Academy of Sciences in the aftermath of the events of August 1968. Together with other officers of the Federation I made representations on his behalf at a high level with a view to ensuring that necessary facilities to enable him to continue his scientific work were made available to him. Although, however, he continued to work in the Institute he was not restored to his former position. According to information supplied to me from official quarters his work at the Institute terminated last autumn when he was three years past the usual retiring age of 60 for scientific workers who do not hold university chairs.

Academician Malek is a most distinguished and talented microbiologist who, in my opinion, still has very much to give both to Czechoslovakia and to world science. Speaking personally, therefore, I would deplore a regulation obliging a scientist to retire while still capable of first class scientific work no matter in which country it occurred. Nevertheless, one must surely concede that questions such as retirement age in a particular country are matters for the people of that country to determine. E. H. S. BURHOP World Federation of Scientific Workers, London, UK 